\title{
Agroclimatic Conditions for Growing Sorghum bicolor L. Moench, under Irrigation Conditions in Mexico
}

\author{
Genovevo Ramírez-Jaramillo ${ }^{1}$, Mónica Guadalupe Lozano-Contreras ${ }^{2 *}$, Jorge H. Ramírez-Silva1 \\ ${ }^{1}$ Centro de Investigación Regional Sureste del Instituto Nacional de Investigaciones Forestales, Agrícolas y Pecuarias (INIFAP), \\ Mérida, Yucatán, México \\ ${ }^{2}$ Campo Experimental Mocochá del Instituto Nacional de Investigaciones Forestales, Agrícolas y Pecuarias (INIFAP), Mocochá, \\ Yucatán, México \\ Email: ^lozano.monica@inifap.gob.mx
}

How to cite this paper: Ramírez-Jaramillo, G., Lozano-Contreras, M.G. and Ramírez-Silva, J.H. (2020) Agroclimatic Conditions for Growing Sorghum bicolor L. Moench, under Irrigation Conditions in Mexico. Open Access Library Journal, 7: e6423.

https://doi.org/10.4236/oalib.1106423

Received: May 14, 2020

Accepted: June 7, 2020

Published: June 10, 2020

Copyright (๑) 2020 by author(s) and Open Access Library Inc.

This work is licensed under the Creative Commons Attribution International License (CC BY 4.0).

http://creativecommons.org/licenses/by/4.0/

\begin{abstract}
Faced with the possible depletion of fossil fuels and the growing demand for energy; the liquid biofuels are being considered as a renewable energy alternative with low impact on carbon emissions. Sweet sorghum (Sorghum bicolor (L) Moench) is a good alternative as it has several advantages in relation to other plant species. Given the interest of the Mexican Government to promote biofuels and $S$. bicolor in particular, this work aimed to spatially delimit the optimal and suboptimal areas to produce this crop in Mexico. The database information considered was the crop agro-ecological requirements for optimal production under irrigation conditions. To process and analyze the information, the QGIS version 3.6 software was used. In high potential areas all variables interact favorably for best crop development and in the suboptimal ones both climatic and edaphological factors interact properly with some limitations; in the unsuitable areas all factors are constraining ones. The study quantified more than 19 million hectares with high optimal conditions under irrigation conditions. The states with the largest areas to produce sweet sorghum are: Veracruz, Campeche, Tamaulipas, Tabasco, Guanajuato, Sonora, Sinaloa, Nuevo Leon, Michoacan, Chihuahua and Quintana Roo; however, should water is provided, practically, it can be grown in all the states of the country.
\end{abstract}

\section{Subject Areas}

Agricultural Engineering

\section{Keywords}

Biofuels, Alternative, Sweet Sorghum 


\section{Introduction}

The accelerated growing rate of large cities in the world requires a high energy demand which is mainly provided by fossil fuels, generating environmental pollution. Fuel depletion is being predicted in the future soon.

Therefore, exploring renewable energy from different sources is the focus of current research [1]. Biofuels are an energy alternative as they are considered a renewable energy source [2]. One of these sources is bioethanol, which favors the environment, the economy and society [3]. This biofuel is produced from a wide range of crops, such as corn, wheat, barley, sugar cane, cassava, sweet potatoes, sugar beets, sweet sorghum, among others [4]. And more recently with oleaginous, inedible plants, which do not compete directly with food, such as Jatropha curcas [5].

Despite having a wide diversity of potential crops to produce biofuels, sorghum [Sorghum bicolor (L.) Moench] is the most widely used crop due to its broad qualities such as: adaptation to worldwide agroclimatic conditions, it requires $36 \%$ less nitrogen [6] and water compared to sugar cane and corn, and produces more ethanol per hectare per unit of time [7] [8]. It is tolerant to drought, salinity, high temperatures [9] [10] and flooded soils [11]; it has a short growth cycle and is widely adapted.

Sorghum bicolor, is a C4 photosynthesis grass, which forms four carbon compounds [12], which accumulates large amounts of fermentable sugars in the stem and biomass, has wide adaptability and tolerates adverse production conditions, Furthermore, sowing is feasible in areas not suitable for other crops [6] [13]. Therefore, it can be used for the production of refined sugar, alcohol and gasoline, among others [14]. In Mexico, the federal government promotes the production of biofuels without neglecting food security and the efficient use of the raw material derived from agricultural, forestry and livestock activities; as well as that derived from algae and enzymatic and biotechnological processes [15]. The national 2017-2030 agriculture plan in Mexico, considered three strategic bioenergetic crops such as: castor (Ricinus communis) and pinion (Jatropha curcas L.) for biodiesel and sweet sorghum (Sorghum bicolor L.) for bioethanol [16].

However, sweet sorghum, in the country, does not achieve the desired yield potential since green forage production, in both, spring-summer and fall-winter seasons are 20 and $17 \mathrm{t} \cdot \mathrm{ha}^{-1}$ respectively. These are very low yields as compared with new materials evaluated by the National Institute for Forestry, Agriculture and Livestock Research (INIFAP) in the state of Tamaulipas. The Fortuna variety yielded $99.12 \mathrm{t} \cdot \mathrm{ha}^{-1}$ of bio-mass ( $73.5 \mathrm{t} \cdot \mathrm{ha}^{-1}$ of stems) in the 2009 spring-summer season whilst in the fall-winter season 2008-2009 the same variety, obtained 127 tha ${ }^{-1}$ of biomass (94.7 tha ${ }^{-1}$ of stems) under irrigation conditions [17]. Taking into account, the importance of sweet sorghum, as strategic crop, and the interest of the Federal Government to expand the surface with high potential yields; it was considered very important to delimit the best agroclimatic areas for sweet sorghum cultivation. 


\section{Material and Methods}

The study was carried out at the INIFAP Southeast Regional Research Center in the city of Mérida, Yucatán.

\subsection{Agro-Ecological Requirements Determination}

The distribution of crops in the world depends on climatic conditions. Since sowing, the plants are subjected to asynchronous variations of climate elements. These elements are critical factor which determine the probability of success of a crop cultivation [18] [19] [20] [21].

The crop requirements are normally described by agroclimatic ranges and are usually reported by species and even by genotype. The resulted potential areas will depend on the agroclimatic intervals considered in the diagnosis; if real optimal values are taken in to account, then, consequently, the best yields and economic profitability of the crop will be reflected.

Based on the reviewed information to determine the potential areas for $S$. bicolor, under irrigation conditions; it was considered high potential areas where all variables interact favorably for best crop development whilst in the suboptimal conditions the climatic and edaphological factors interact properly but with some limitations; and finally the unsuitable areas where all factors are constraining ones for crop development. Sorghum requirements were determined by consulting the bibliography, databases and expert knowledge.

The soil type (texture, depth, $\mathrm{pH}$, drainage), average annual temperature, altitudes and slopes, among others (Table 1) were the factors considered to regionalize the different potential production areas.

Table 1. Agro-ecological requirements of Sorghum bicolor L. Moench.

\begin{tabular}{|c|c|c|c|c|}
\hline Variable & Unit & Optimal & Suboptimal & No suitable \\
\hline $\begin{array}{l}\text { Average annual } \\
\text { temperature }\end{array}$ & ${ }^{\circ} \mathrm{C}$ & $25-30$ & $\begin{array}{l}20-25 \\
30-35\end{array}$ & $\begin{array}{l}<20 \\
>35\end{array}$ \\
\hline Altitude & $m$ & $0-1000$ & $1000-1200$ & $>1200$ \\
\hline Soil & Types & $\begin{array}{l}\text {-Fluvisols } \\
\text {-Luvisols } \\
\text {-Nitisols } \\
\text {-Regosol } \\
\text {-Andosols } \\
\text {-Phaeozem } \\
\text {-Kastanozem }\end{array}$ & $\begin{array}{l}\text {-Cambisols } \\
\text {-Gleysoles (Slope > 5\%) } \\
\text {-Vertisoles }(\text { Slope > 5\%) } \\
\text {-Calcisoles }\end{array}$ & $\begin{array}{l}\text {-Solonchaks } \\
\text {-Leptosols } \\
\text {-Gleysols (Slope < 5\%) } \\
\text {-Vertisoles (Slope < 5\%) } \\
\text {-Arenosols }\end{array}$ \\
\hline Soil texture & Types & Medium & Light & Heavy \\
\hline Soil Depth & $m$ & $<1$ & 1 to 0.5 & $>50$ \\
\hline Soil pH & Indicator & 6.0 to 7.0 & 7.1 to 8.0 & $\begin{array}{l}<5.5 \\
>8.0\end{array}$ \\
\hline Drainage & Types & $\begin{array}{l}\text { Good } \\
15 \text { to } 20 \% \text { of } \mathrm{O}_{2}\end{array}$ & $\begin{array}{l}\text { Medium } \\
5 \text { to } 15 \% \text { of } \mathrm{O}_{2}\end{array}$ & $\begin{array}{l}\text { Deficient } \\
<\text { of } 5 \% \text { of } \mathrm{O}_{2}\end{array}$ \\
\hline Photoperiod & Hours & 1000 & 800 & 600 \\
\hline
\end{tabular}

Source: Own elaboration based on consultation of experts and different sources of information. 


\subsection{Identification of Potential Sorghum bicolor (L.) Cultivation Areas}

To process and analyze the information, the QGIS version 3.6 software was used [22]. This is a program created by Gary Sherman with the name of Quantum GIS in 2002; it was incubated by OSGeo in 2007 and in 2009 version 1.0 was launched. All QGIS activity takes place within the project which is a collection of associated manageable documents during the session. Projects can contain five types of documents: views, tables, charts, layouts (or printed outputs), and scripts. The corresponding file format is ${ }^{*}$.qgs.

The project is formed by particular configurations saved in a data frame. The system can also accept: the coordinate reference system, the composition of the layers, the symbology of the layers, the configuration of the system and the network. The QGIS also ensures that the map layers are displayed in the correct coordinate reference system (provided the first settings are correct).

In this work, vector maps ${ }^{*}$.shp were used in which geoprocesses of cuts, dissolutions, unions and intersections were carried out. Once reclassified, based on crop requirements, the intersection of the variables was computerized in order to generate and de-limit optimal, suboptimal and unsuitable potential areas (Figure 1). Maps were generated through cartographic intersections between polygons, and potential classes were also defined. As a result, the final map, based on the inter-sections, provided in-formation about potential growing areas.

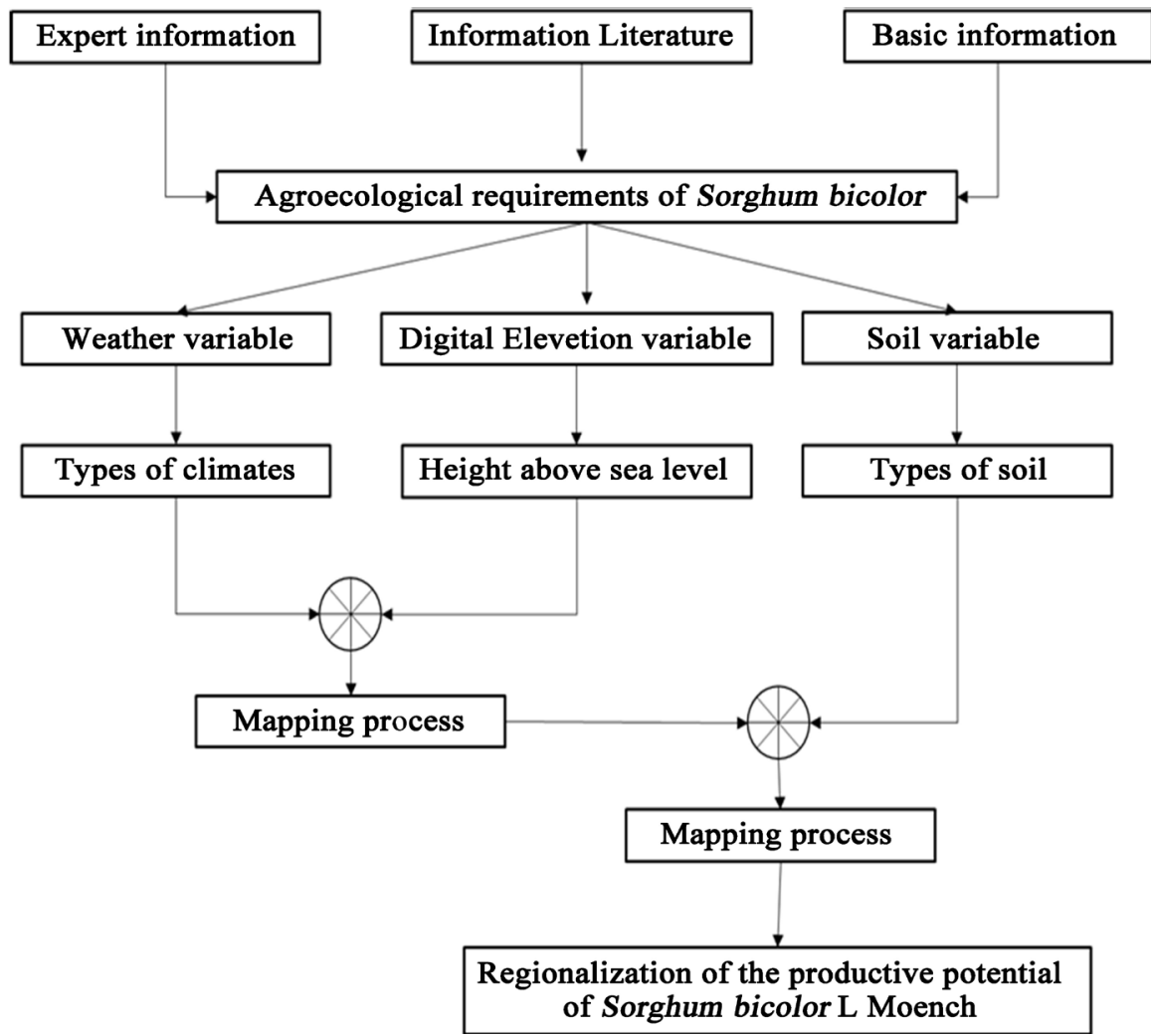

Figure 1. Methodological model used to determine the production potential. 


\section{Results and Discussion}

\subsection{Temperature}

Sweet sorghum can be cultivated in large parts of the Mexican Republic; however, there is a great affinity for the coasts, especially in the Gulf of Mexico (Figure 2). This plant develops well in warm climate conditions, with moderate and well distributed rains according to Pérez, 2010 [23]; the ideal temperature should be above $18^{\circ} \mathrm{C}$ in order to germinate and grow properly [24].

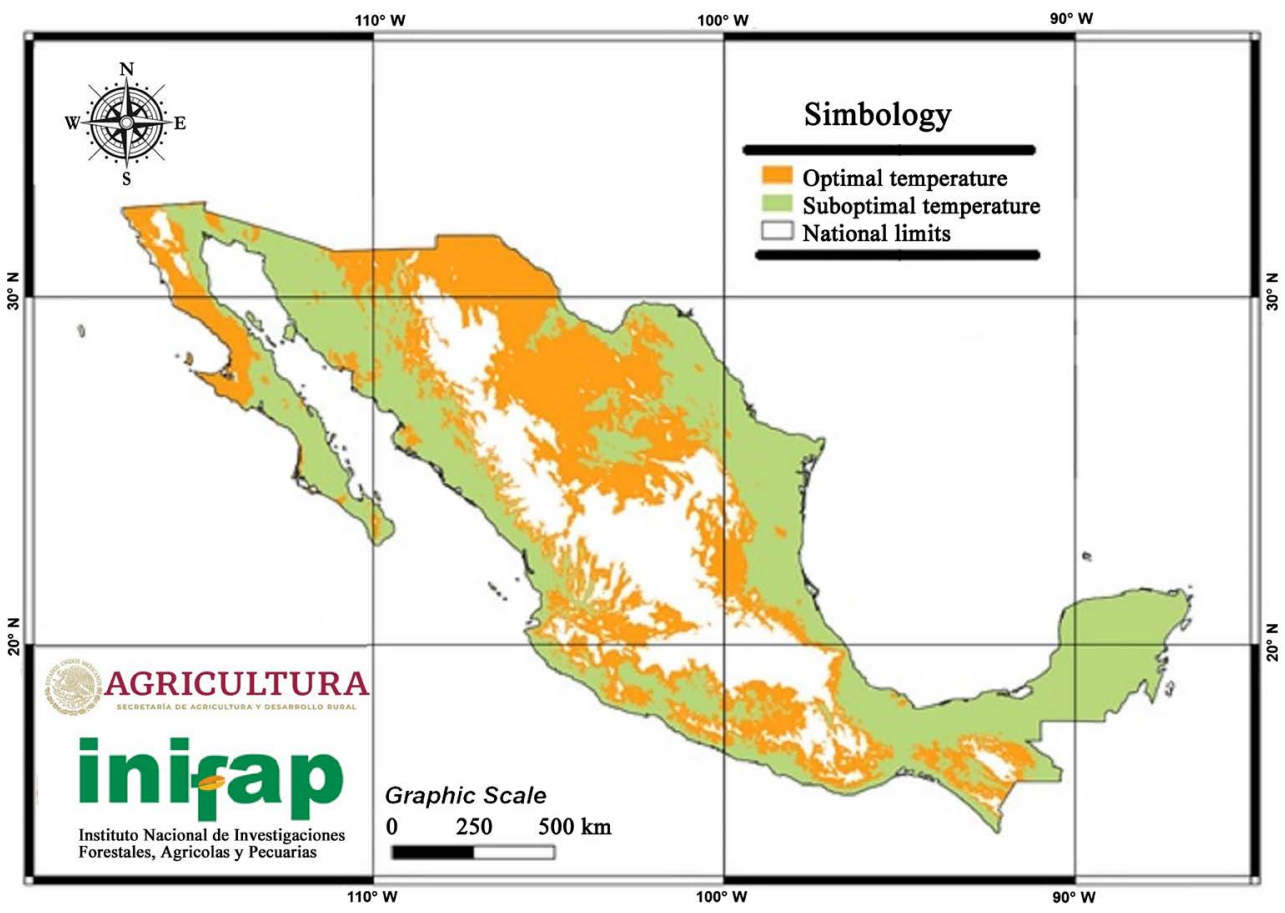

Figure 2. Optimal and suboptimal temperatures for sweet sorghum in Mexico.

The optimal growth temperature is from $26.7^{\circ} \mathrm{C}$ to $29.4^{\circ} \mathrm{C}$. Temperatures above $38^{\circ} \mathrm{C}$ are harmful, despite the fact that this plant tolerates heat and drought better than corn [25]. Other authors such as Acuña et al., (2002) [26], suggest good temperatures for sweet corn of $24^{\circ} \mathrm{C}$ to $30^{\circ} \mathrm{C}$. During the germination phase, it needs temperatures of $12^{\circ} \mathrm{C}$ to $13^{\circ} \mathrm{C}$, therefore, temperatures below these are considered unsuitable; growth is activated above $15^{\circ} \mathrm{C}$, with the optimum around $32^{\circ} \mathrm{C}$ [27]. When temperature decreases, during flowering, grain yield can be reduced; sterility of the spikelets and pollen grain viability is also affected [28]. On the other hand, very high temperatures (greater than $38^{\circ} \mathrm{C}$ ), after flowering, reduce the final weight of the grain and cause abortion of flowers [23]. By instance, it has been suggested that $27^{\circ} \mathrm{C}$, is the optimal temperature; being $21^{\circ} \mathrm{C}$ the minimum temperature for good growth [29].

\subsection{Irrigation Requirements}

At the national level, sorghum is produced under both irrigation and rainfed conditions. During the 2012-2016 period, 35.5\% of the total sorghum area was har- 
vested under irrigation conditions, producing $47.3 \%$ of the total production with an average yield of $4.9 \mathrm{Mg} \cdot \mathrm{ha}^{-1}$, while $64.5 \%$ of the total surface harvested was cultivated under rainfed conditions producing $52.7 \%$ of the total production with an average yield of $3 \mathrm{Mg} \cdot \mathrm{ha}^{-1}$ [30].

Sweet sorghum adapts to different humidity conditions, so rainwater is sufficient to complete its vegetative cycle, especially in the sub-humid tropics [31], where rainfall ranged between 700 and $1600 \mathrm{~mm}$ per year. However, additional water by irrigation is needed in areas where the rainfall distribution is erratic and less than $700 \mathrm{~mm}$ per year. Provided water is important especially in the emergency stages, vegetative development, stem and spikelet formation according to studies carried out by INIFAP, in the Experimental Field Station of Valle de Mexicali [32]. When necessary it is recommended to apply $10 \mathrm{~cm}$ of water before sowing. Two supply irrigations should be added, with $20 \mathrm{~cm}$ each; the first at 40 days after sowing and the second at 65 - 70 days after planting [17] [33].

\subsection{Elevation}

Due to its high temperature requirements, sweet sorghum is rarely cultivated beyond $1800 \mathrm{~m}$ high; however, in the African continent it is cultivated between $400 \mathrm{~m}$ and $2500 \mathrm{~m}$ altitude [34]. In the American continent, it adapts to an altitude ranging between 20 and 850 meters above sea level [35] considered as optimal for its development. It has been suggested that this plant can grow from 0 to 1500 meters above sea level [23]. It is common to find good areas close to water bodies, with low elevation, and favorable warm and humid climate. In Mexico, the optimal and suboptimal altitude for sweet sorghum is shown in Figure 3.

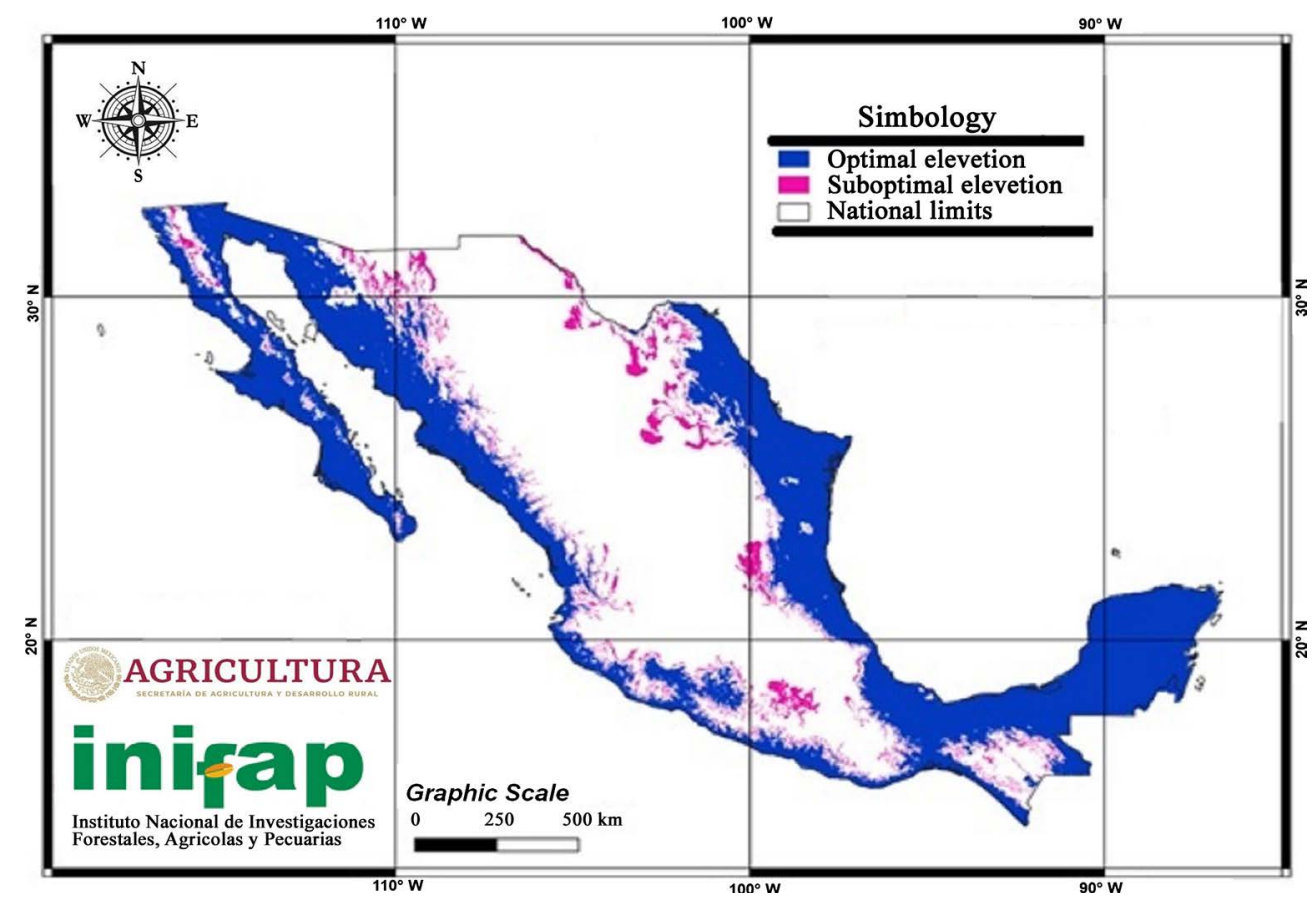

Figure 3. Optimal and suboptimal elevations for sweet sorghum in Mexico. 


\subsection{Soils}

The best soils for Sorghum bicolor (L.) are those of high fertility, sandy, loamy or clayey texture [23] [35]. Sweet sorghum prefers deep soils, without excess salts, with good drainage, without hardened layers. It is moderately tolerant to soils with some salinity and/or alkalinity. According to studies the presence of calcium carbonate in the soil increases the content of sucrose in the stem and leaves [36] [37] [38] [39]. It grows better, under salinity conditions, than other crops such as wheat, soybeans and corn.

The soils must have good drainage, since excessive humidity affects the normal development of the plants. The edaphic requirements of the crop [25] [35] [40] are classified as: Fluvisols, Regosols, Luvisols, Nitisols, Andosols, Phaeozam and Kastañozem among others. These soils have a depth greater than $50 \mathrm{~cm}$, with good moisture retention and very porous. In Mexico, the distribution of optimal and suboptimal soils is being shown in Figure 4.

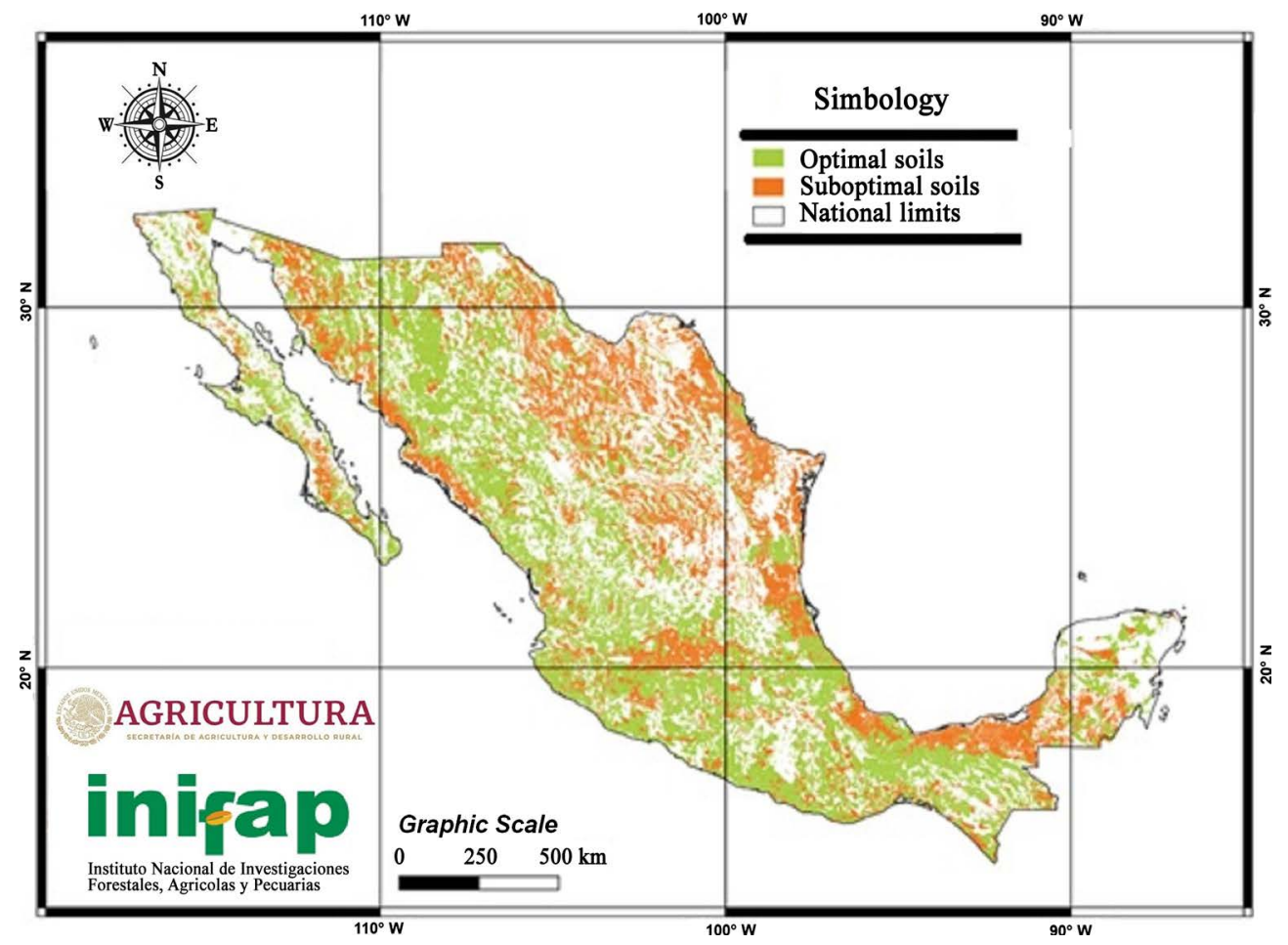

Figure 4. Optimal and suboptimal soils for growing sweet sorghum in Mexico.

\subsection{Slope}

It is considered that 0 to $16 \%$ is the optimal slope range for good crop development [41], and $16 \%$ to $20 \%$ as a sub-optimum one. Naidu et al., (2006) [42] assures that soil inclination should be less than $16 \%$ when the purpose is to produce the greatest amount of biomass for sugar production. Mexico is a country characterized by having a significant surface area with slopes between 0 and $16 \%$; while in contrast, slopes of $16 \%-20 \%$ are mainly found in the mountain ranges of the country (Figure 5). 


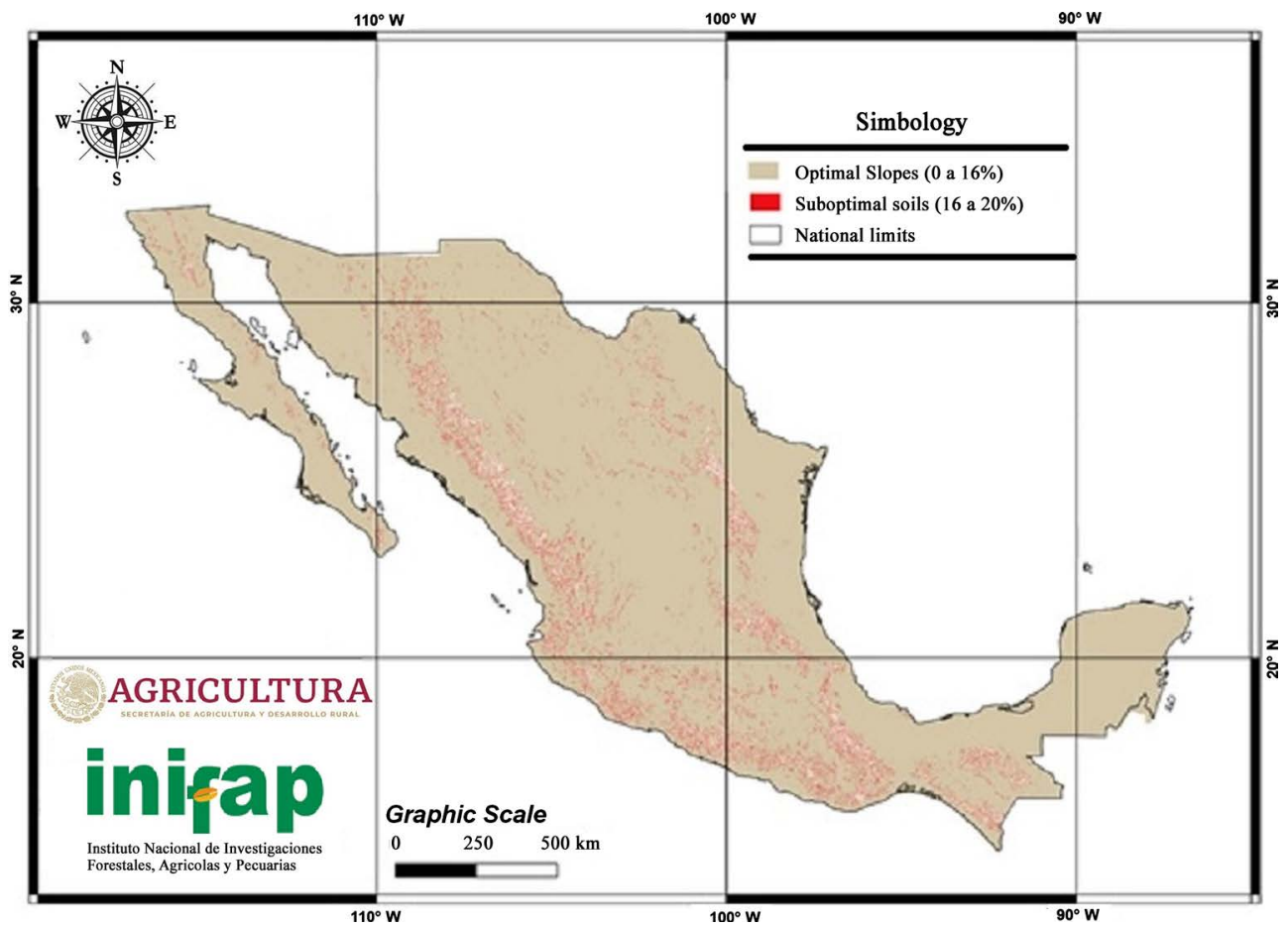

Figure 5. Optimal and suboptimal slopes for growing sweet sorghum in Mexico.

\section{6. $\mathrm{pH}$}

Sweet sorghum grows well in soils with $\mathrm{pH}$ ranging between 5.5 and 8.5; however, the ideal pH is between 5.5 and 6.5 [23] [43]. It supports salt and it is suggested that sugary varieties require the presence of calcium carbonate in the soil, which increases the sucrose content of the stems and leaves [23].

\subsection{Photoperiod}

The environment plays an important role in sugar production [44]. Reports indicate that sweet sorghum is very efficient to produce sugar in warm environments [45] [46] with high light intensity [45]. However, it is considered a short day crop ( $<12$ hours), although there are neutral day cultivars [47]. Panicle formation and flowering accelerates in short days while delaying in long days [48].

\subsection{Potential Cultivation Zones for Sweet Sorghum under Irrigation}

Sorghum bicolor L. Moench is one of the oldest crops and currently one of the most important cereals in the world [49]. It grows well in all continents, in tropical, subtropical and temperate regions; in lands of medium and low agricultural aptitude, and especially suitable for regions with little precipitation [50]. Sorghum can be cultivated in large parts of the Mexican Republic; however, the best region is located in the coasts, especially in the Gulf of Mexico, where soils such as Cambisol and Vertisol type are the most common. On the other hand, it is suggested that Tamaulipas and Guanajuato are the best states (Figure 6, Table 2) where sorghum can be produced with better yields under irrigation; a practice that is currently carried out intensively. 


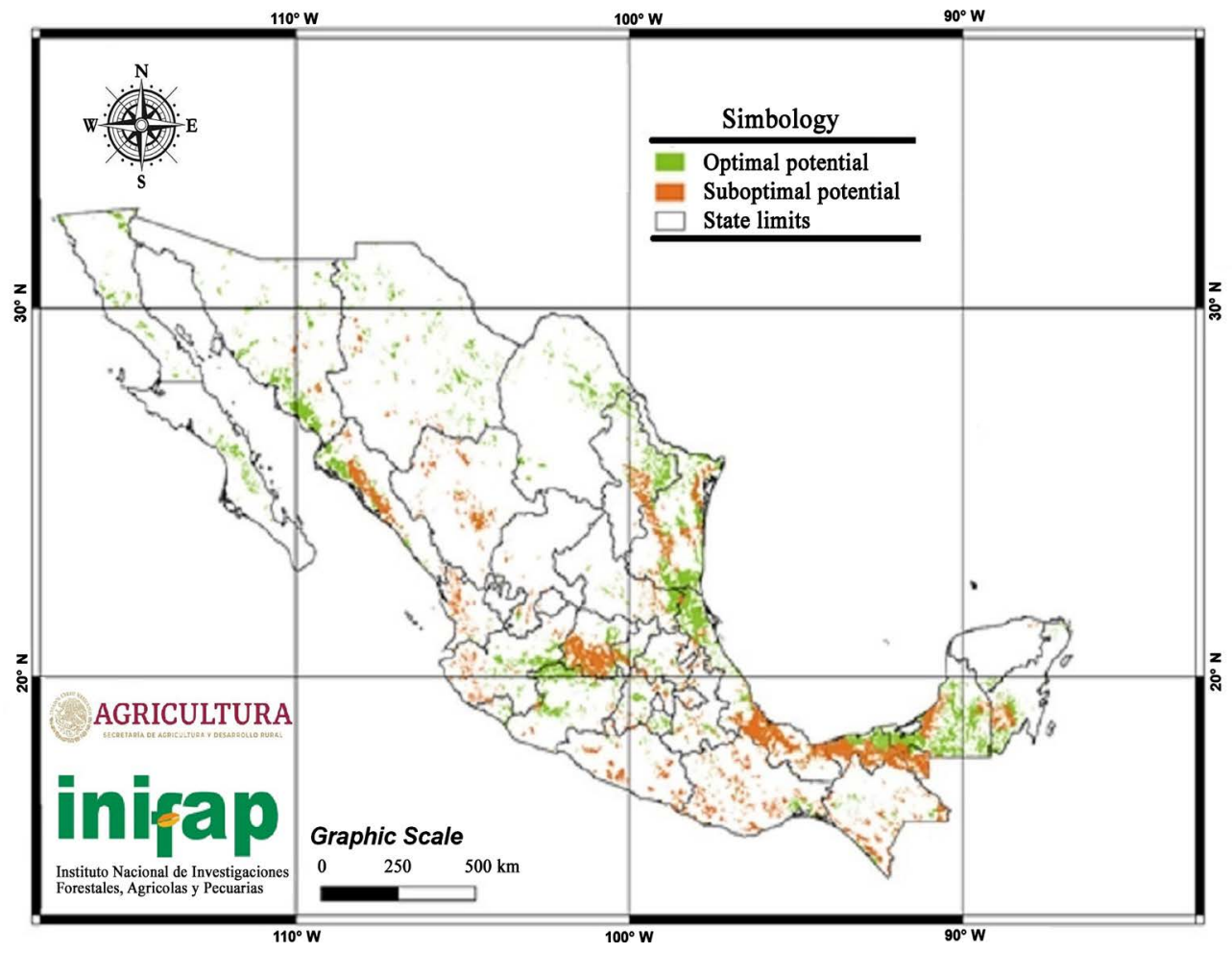

Figure 6. Optimal and suboptimal areas where sweet sorghum can be grown under irrigation conditions in Mexico.

Table 2. Potential areas for growing Sorghum bicolor L. Moench. under irrigation in Mexico.

\begin{tabular}{cccc}
\hline State & Optimal areas (ha) & Suboptimal areas (ha) & Total (ha) \\
\hline Baja California & 358,510 & 0 & 358,510 \\
Baja California Sur & 259,440 & 0 & 259,440 \\
Campeche & $2,189,687$ & 673,483 & $2,863,170$ \\
Chiapas & 515,826 & 934,821 & $1,450,647$ \\
Chihuahua & 783,518 & 164,450 & 947,968 \\
Coahuila & 468,205 & 0 & 468,205 \\
Colima & 47,767 & 14,510 & 62,277 \\
Ciudad de Mexico & 985 & 2130 & 3115 \\
Durango & 254,036 & 508,892 & 762,928 \\
Guanajuato & $1,211,451$ & $1,030,421$ & $2,241,872$ \\
Guerrero & 79,529 & 512,416 & 591,945 \\
Hidalgo & 192,174 & 192,641 & 384,815 \\
Jalisco & 596,650 & 392,350 & 989,000 \\
Estado de Mexico & 228,639 & 197,753 & 426,392 \\
\hline
\end{tabular}




\section{Continued}

\begin{tabular}{|c|c|c|c|}
\hline Michoacan & 935,902 & 241,645 & $1,177,547$ \\
\hline Morelos & 103,467 & 16,442 & 119,909 \\
\hline Nayarit & 36,852 & 304,429 & 341,281 \\
\hline Nuevo Leon & 956,575 & 318,339 & 1274,914 \\
\hline Oaxaca & 346,328 & $1,174,983$ & 521,312 \\
\hline Puebla & 191,160 & 202,616 & 393,776 \\
\hline Queretaro & 252,719 & 173,523 & 426,242 \\
\hline Quintana Roo & 622,307 & 268,560 & 890,867 \\
\hline San Luis Potosi & 478,354 & 188,817 & 667,171 \\
\hline Sinaloa & $1,000,633$ & 677,399 & $1,678,032$ \\
\hline Sonora & $1,108,679$ & 123,608 & $1,232,287$ \\
\hline Tabasco & $1,587,146$ & $1,531,283$ & $3,118,429$ \\
\hline Tamaulipas & $1,994,243$ & 848,451 & $2,842,694$ \\
\hline Tlaxcala & 3572 & 49,483 & 53,055 \\
\hline Veracruz & $2,250,587$ & $1,555,576$ & $3,806,163$ \\
\hline Yucatan & 55,446 & 10,200 & 65,646 \\
\hline Zacatecas & 70,968 & 86,844 & 157,812 \\
\hline TOTAL & $19,211,355$ & $12,396,065$ & $31,607,420$ \\
\hline
\end{tabular}

\section{Conclusion}

There are optimal agro-ecological conditions to produce sweet sorghum under irrigation conditions in order to improve its productivity in the Mexican Republic. The states with the largest areas to produce sweet sorghum are: Veracruz, Campeche, Tamaulipas, Tabasco, Guanajuato, Sonora, Sinaloa, Nuevo Leon, Michoacan, Chihuahua and Quintana Roo; however, practically it can be grown in all the states of the country if water is provided. The high optimal potential areas, found in this work, far exceed the current surface planted. The study quantified more than 19 million hectares with high optimal conditions when irrigation is supplied.

\section{Conflicts of Interest}

The authors declare no conflicts of interest regarding the publication of this paper.

\section{References}

[1] Kumar, S.R., Ramanjaneyulu, A.V. and Krishna, A. (2010) A Decadal Analysis of Improved Sorghum (Sorghum bicolor) Cultivar Response to Fertilizer Application in Rainy Season and a Hypothetical Grain Production Model. Indian Journal of 
Agricultural Sciences, 80, 786-790.

https://krishi.icar.gov.in/jspui/bitstream/123456789/8395/1/A_decadal_analysis_of_ improved_sorghum_Sorghum_bic.pdf

[2] Anglani, C. (1998) Sorghum for Human Food-A Review. Plant Foods for Human Nutrition, 52, 85-95. https://doi.org/10.1023/A:1008065519820

[3] Montiel Montoya, J. (2010) Potential and Environmental Risk of Bioenergetics in Mexico. Ra Ximhai, 6, 57-62. https://www.redalyc.org/pdf/461/46112896008.pdf https://doi.org/10.35197/rx.06.01.2010.08.jm

[4] Drapcho, C.M. (2008) Biofuel Feedstocks, Chapter 4. In: Drapcho, C.M., Nghim, N.P. and Walker, T., Eds., Biofuels Engineering Process Technology, McGraw-Hill, New York, 69-78.

http://www.mhprofessional.com/downloads/products/0071487492/DrapchoCh4.pdf

[5] Errasti Cabrera, M., Piloto Rodríguez, R., Ferrer Frontela, N., Melo Espinoza, E., Ahmed, D.O., Werner, A. and Goyos Pérez, L. (2013) Characterization of a Diesel Engine Working with Jatropha Oil and Diesel Fuel Mixtures. Energetic Engineering, 34, 198-207. http://scielo.sld.cu/scielo.php?script=sci_arttext\&pid=S1815-59012013000300003

[6] Ratnavathi, C.V., Kalyana Chakravarthy, S., Komala, V.V., Chavan, U.D. and Patil, J.V. (2011) Sweet Sorghum as Feedstock for Biofuel Production: A Review. Sugar Tech, 13, 399-407. https://link.springer.com/article/10.1007/s12355-011-0112-2 https://doi.org/10.1007/s12355-011-0112-2

[7] Geng, S., Hills, F.J., Johnson, S.S. and Sah, R.N. (1989) Potential Yields and On-Farm Ethanol Production Cost of Corn, Sweet Sorghum, Fodder Beet, and Sugar Beet. Journal of Agronomy and Crop Science, 162, 21-29. https://doi.org/10.1111/j.1439-037X.1989.tb00683.x

[8] Reddy, B.V., Ramesh, S., Reddy, P.S., Ramaiah, B., Salimath, P.M. and Kachapur, R. (2005) Sweet Sorghum. A Potential Alternate Raw Material for Bioethanol and Bioenergy. International Sorghum and Millets Newsletter, 46, 79-86. http://oar.icrisat.org/1234

[9] Murray, S.C. (2008) Genetic and Phenotypic Diversity in Sorghum for Improvement as a Biofuel Feedstock. PhD Thesis, Cornell University, Ithaca, 72. https://ecommons.cornell.edu/handle/1813/11052

[10] Chuck-Hernandez, C., Perez-Carrillo, E., Heredia-Olea, E. and Serna-Saldivar, S.O. (2011) Sorghum as a Multifunctional Crop for Bioethanol Production in Mexico: Technologies, Advances and Improvement Opportunities. Mexican Journal of Chemical Engineering, 10, 529-549.

http://www.scielo.org.mx/scielo.php?script=sci_abstract\&pid=S1665-273820110003 00018\&lng=es\&nrm=iso

[11] Almodares, A., Hadi, M.R. and Dosti, B. (2007) Effects of Salt Stress on Germination Percentage and Seedling Growth in Sweet Sorghum Cultivars. Journal of Biological Sciences, 7, 1492-1495. https://scialert.net/abstract/?doi=jbs.2007.1492.1495 https://doi.org/10.3923/jbs.2007.1492.1495

[12] Khawaja, C., Janssen, R., Rutz, D., Luquet, D., Trouche, G., Reddy, B., Rao, P.S., Basavaraj, G., Schaffert, R., Damasceno, C., Parella, R., Zacharias, A., Bushmann, R., Rettenmaier, N., Reinhardt, G., Monti, A., Lizarazu, W.Z., Amaducci, S., Marocco, A., Snijman, W., Shargie, N., Terblanche, H., Zavala-García, F. and Braconnier, S. (2014) Energy Sorghum: An Alternative Energy Crop. A Handbook. WIP Renewable Energies, Munich, 13. http://oar.icrisat.org/9049

[13] Calviño, M. and Messing, J. (2012) Sweet Sorghum as a Model System for Bioenergy 
Crops. Current Opinion in Biotechnology, 23, 323-329.

https://doi.org/10.1016/j.copbio.2011.12.002

[14] Díaz, F.A., Espinosa, R.M. and Ortiz, C.F.E. (2016) Promotion of Biomass and Sugar Content in Sweet Sorghum through Organic Fertilizers and Arbuscular Mycorrhiza. International Journal of Environmental Pollution, 32, 353-360.

[15] Official Journal of the Federation (DOF) (2008) Chamber of Deputies. H. Congress of the Union. Secretary General and Secretary of Parliamentary Services. Bioenergetics Promotion and Development Law. Documentation Center, Mexico, 12.

[16] Ministry of Agriculture, Livestock, Rural Development, Fishing and Food (SAGARPA) (2017) Bioenergetics: Castor Oil Plant, Jatropha curcas, Sweet Sorghum. National Agricultural Plan 2017-2030. 1-27.

https://www.gob.mx/cms/uploads/attachment/file/257070/Potencial-Bioenerg_ticos .pdf

[17] Montes, G.N., Vargas, V.E., Salinas, G.J., Espinosa, R.M. and Loredo, P.R. (2013) Sweet Sorghum Production Technology for Ethanol Elaboration in Tamaulipas. Leaflet 21. Río Bravo Experimental Field Station. National Institute of Forest, Agricultural and Livestock Research, Río Bravo, $26 \mathrm{p}$. https://pdfs.semanticscholar.org/d16e/0496f3400b0bbe904cd62d3dff4cecc5185c.pdf

[18] Benacchio, S.S. (1982) Some Agroecological Requirements in 58 Crop Species with Production Potential in the American Tropic. FONAIAP National Agricultural Research Center, Ministry of Agriculture and Breeding, Maracay, 35-39.

[19] Doorenbos, J. and Kassam, A.H. (1979) Effects of Water on Crop Yields. FAO Study: Irrigation and Drainage No. 33, Rome.

[20] Food and Agriculture Organization of the United Nations (FAO) (1993) Ecocrop, Ecological Requirements of Plant Species, Database. Rome.

[21] García, E. (1988) Modifications to the Köppen Climate Classification. UNAM, México.

[22] QGIS Geographic Information System (2019) Open Source Geospatial Foundation Project.

[23] Pérez, A., Saucedo, O., Iglesias, J., Wencomo, Hilda, B., Reyes, F., Oquendo, G. and Milián, I. (2010) Characterizatión and Potential of Sorghum Grain (Sorghum bicolor L. Moench). Pastures and Forages, 33, 1-25. http://scielo.sld.cu/pdf/pyf/v33n1/pyf01110.pdf

[24] Neild, R.E., Logan, J. and Cardenas, A. (1983) Growing Season and Phenological Response of Sorghum as Determined from Simple Climatic Data. Agricultural Meteorology, 30, 35-48. https://doi.org/10.1016/0002-1571(83)90039-0

[25] Baradas, M.W. (1994) Crop Requirements of Tropical Crops. In: Griffiths, J.F., Ed., Handbook of Agricultural Meteorology, Oxford Univ. Press, New York, 189-202.

[26] Acuña, J., et al. (2002) Agricultural Manual. Organic Technologies of the Self-Sufficient Integral Farm. Peasant Youth Homes Foundation, Bogota, 1071.

[27] Dial, H.L. (2012) Plant Guide for Sorghum (Sorghum bicolor L.). USDA Natural Resources Conservation Service, Tucson Plant Materials Center, Tucson. https://plants.usda.gov/plantguide/pdf/pg_sobi2.pdf

[28] Assefa, Y., Staggenborg, S.A. and Prasad, V.P.V. (2010) Grain Sorghum Water Requirement and Responses to Drought Stress: A Review. Crop Management, 9, 1-11. https://www.researchgate.net/publication/260421900_Grain_Sorghum_Water_Requ irement_and_Responses_to_Drought_Stress_A_Review https://doi.org/10.1094/CM-2010-1109-01-RV 
[29] Correa, U.A. (2001) Sorghum in Animal Production. CREAS. West Zone, Information Gazette No. 166. Argentine Animal Production Site. 1-4.

http://www.produccion-animal.com.ar/produccion_y_manejo_pasturas/maiz_sorg o/39-sorgo_forrajero_en_produccion_animal.pdf

[30] López Avendaño, J.E., Rodríguez, J.C., Martínez Gallardo, J.Á., Lizárraga Jiménez, R. and Díaz Valdés, T. (2019) Use of FAO-56 and Scintillometer to Estimate Evapotranspiration of Grain Sorghum (Sorghum bicolor L.) and Its Components: Soil Evaporation and Plant Transpiration. Latinoamerican Terra, 37, 141-150.

https://doi.org/10.28940/terra.v37i2.393

[31] Álvarez, C.M. and Montes, G.N. (2017) Production Technology for Sweet Sorghum [Sorghum bicolor (L.) Moench] as a Source for Obtaining Bioethanol in the Sub-Humid Tropics of the State of Jalisco. Technical Brochure No. 15. INIFAP-CIRPAC. Tecomán Experimental Field Station, Tecomán, 24 p.

https://vun.inifap.gob.mx/VUN_MEDIA/BibliotecaWeb/_media/_folletotecnico/10 29_4702_Tecnolog\%c3\%ada_de_producci\%c3\%b3n_de_sorgo_dulce_Sorghum_bic olor_l._Moench_como_fuente_para_la_obtenci\%c3\%b3n_de_bioetanol_en_el_tr\%c 3\%b3pico_subh\%c3\%bamedo_del_estado_de_Jalisco.pdf

[32] Alvarado, P.J.I. (2015) Project Report. Effect of the Planting Method, Planting Density and Irrigation in the Biomass and Sugar Production of Sweet Sorghums Evaluated in Baja California. INIFAP. Experimental Field Station of Valle de Mexicali, Mexicali, $6 \mathrm{p}$.

[33] Pecina Quintero, V., Herrera Corredor, C., Hernández Martínez, M., Montes García, N. and Moreno Gallegos, T. (2017) Sweet Sorghum Production Technology (Sorghum bicolor (L.) Moench) in Guanajuato. Technical Brochure No. 37. National Institute of Agricultural Forestry and Livestock Research, Regional Research Center, Bajio Celaya Experimental Field Center, Guanajuato.

https://vun.inifap.gob.mx/VUN_MEDIA/BibliotecaWeb/_media/_folletotecnico/10 47_4732_Tecnolog\%c3\%ada_de_producci\%c3\%b3n_de_sorgo_dulce_(Sorghum_bi color_(L.)_Moench)_en_Guanajuato.pdf

[34] Habte, N., Seyoum, A. and Gebreyohannes, A. (2017) Evaluation of Yield Performance of Intermediate Altitude Sorghum (Sorghum bicolor (L.) Moench) Genotypes Using Genotype x Environment Interaction Analysis and GGE Biplot in Ethiopia. International Journal of Trend in Research and Development, 3, 27-35. http://www.ijtrd.com/papers/IJTRD3499.pdf

[35] Buestan, R.H. (1994) Stability Parameters and Cultivar Selection. National Institute for Agricultural Research, Boliche Experimental Station.

[36] Agri-Food and Fisheries Information and Statistics Service (SIAP) (2010) Agricultural Consultation Information System (SIACON). Version 1.1. Secretary of Agriculture, Livestock, Rural Development, Fishing and Food, Mexico.

https://nube.siap.gob.mx/cierreagricola

[37] Almodares, A., Taheri, R. and Adeli, S. (2007) Inter-Relationship between Growth Analysis and Carbohydrate Contents of Sweet Sorghum Cultivars and Lines. Journal of Environmental Biology, 28, 527-531. http://www.jeb.co.in/journal_issues/200707_jul07/paper_01.pdf

[38] Almodares, A., Hadi, M.R. and Dosti, B. (2008) The Effects of Salt Stress on Growth Parameters and Carbohydrate Contents in Sweet Sorghum. Research Journal of Environmental Sciences, 2, 298-304. https://doi.org/10.3923/rjes.2008.298.304 http://docsdrive.com/pdfs/academicjournals/rjes/2008/298-304.pdf

[39] Almodares, A., Hadi, M.R. and Ahmadpour, H. (2008) Sorghum Stem Yield and Soluble Carbohydrates under Different Salinity Levels. African Journal of Biotech- 
nology, 7, 4051-4055.

https://academicjournals.org/journal/AJB/how-to-cite-article/829EA628200

[40] Food and Agriculture Organization of the United Nations (FAO) (2014) Ecocrop, Ecological Requirements of Plant Species, Database. Rome.

[41] Kahsay, A., Mitiku, H., Girmay, G. and Muktar, M. (2018) Land Suitability Analysis for Sorghum Crop Production in Northern Semi-Arid Ethiopia: Application of GIS-Based Fuzzy AHP Approach. Cogent Food \& Agriculture, 4, 1-24. https://www.tandfonline.com/doi/full/10.1080/23311932.2018.1507184

[42] Naidu, L.G.K., Ramamurthy, V., Challa, O., Hegde, R. and Krishnan, P. (2006) Manual Soil-Site Suitability Criteria for Major Crops. National Bureau of Soil Survey and Land Use Planning (I CAR), Amravati.

[43] Elaalem, M. (2012) Land Suitability Evaluation for Sorghum Based on Boolean and Fuzzy-Multi-Criteria Decision Analysis Methods. International Journal of Environmental Science and Development, 3, 357-361.

http://citeseerx.ist.psu.edu/viewdoc/download?doi=10.1.1.678.5493\&rep=rep1\&type=pdf https://doi.org/10.7763/IJESD.2012.V3.247

[44] Williams-Alanís, H., Zavala-García, F., Arcos-Cavazos, G., Rodríguez-Vázquez, M.C. and Olivares-Sáenz, E. (2017) Agronomic Characteristics Associated with Bioethanol Production in Sweet Sorghum Genotypes. Mesoamerican Agronomy, 28, 549-563. http://www.mag.go.cr/rev_meso/v28n03_549.pdf https://doi.org/10.15517/ma.v28i3.26690

[45] Rooney, L. and Serna-Saldívar, S. (2000) Sorghum. In: Kulp, K. and Ponte, J., Eds., Handbook of Cereal Science and Technology, Marcel Dekker, New York, 149-176.

[46] Almodares, A. and Hadi, M.R. (2009) Production of Bioethanol from Sweet Sorghum: A Review. African Journal of Agricultural Research, 4, 772-780. https://academicjournals.org/journal/AJAR/article-abstract/6DDEDD738826

[47] Dendy, D.A.V. (1995) Sorghum and Millets Chemistry and Technology. American Association of Cereal Chemists, St. Paul, Universidad de Wisconsin, Madison.

[48] Baradas, M.W. (1994) Crop Requirements of Tropical Crops. In: Griffiths, J.F., Ed., Handbook of Agricultural Meteorology, Oxford University Press, New York, 10-15.

[49] Serna-Saldivar, S. (2010) Cereal Grains: Properties, Processing, and Nutritional Attributes. CRC Press, Taylor \& Francis Group, Boca Raton, 22 p.

https://books.google.com.mx/books?id=OgzSBQAAQBAJ\&lpg=PA108\&ots=uQoeP DFQaI\&dq=Sorghum.\%20En\%3A\%20Handbook\%20of\%20Cereal\%20Science\%20a nd\%20Technology\%2C\%20(Kulp\%2C\%20K.\%2C\%20Ponte\%2C\%20J.\%2C\%20eds.) \%20Marcel\%20Dekker\%2C\%20New\%20York\%2C\%20USA\&hl=es\&pg=PA12\#v=o nepage\&q\&f=false

[50] Tobin (2010) Sweetened Sorghum as a Promising Energy Crop for NOA. http://www.tobin.com.ar/?El_Sorgo_Azucarado\%3A_Un_cultivo_energ\%E9tico_pro $\underline{\text { misorio_para_el_NOA\&page }=\text { ampliada\&id }=54 \& \_s=\& \_p a g e=\text { informacion_comercial }}$ 